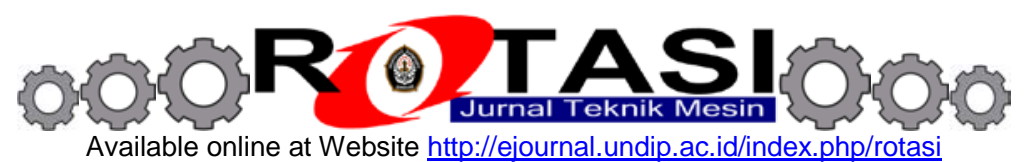

\title{
RANCANG BANGUN ALAT PERMAINAN EDUKATIF JENIS GELINDING KELERENG UNTUK PENDIDIKAN ANAK USIA DINI KELOMPOK USIA 4-6 TAHUN
}

\author{
${ }^{*}$ Nila Kusumaningtyas ${ }^{\mathrm{a}}$, **Yuris Setyoadi ${ }^{\mathrm{b}}$ \\ ${ }^{a}$ Program Studi Pendidikan Anak Usia Dini, Fakultas Ilmu Pendidikan, Universitas PGRI Semarang \\ ${ }^{b}$ Program Studi Teknik Mesin, Fakultas Teknik, Universitas PGRI Semarang \\ Jl. Dr. Cipto No.24 Sidodadi Timur Semarang \\ *nilakusumaningtyas@upgris.ac.id, ***yrissetyoadi@upgris.ac.id
}

\begin{abstract}
ABSTRAK
Pendidikan bagi anak usia dini merupakan proses pendidikan yang sangat fundamental sebagai kerangka dasar pembentukan dan pengembangan dasar-dasar pengetahuan, sikap dan ketrampilan pada anak. Keberhasilan proses pendidikan diusia dini menjadi dasar sangat penting untuk proses pendidikan selanjutnya. Alat Permainan Edukatif (APE) meerupakan sarana yang dapat dipergunakan sebagai alat permainan yang mengandung makna pendidikan, dan dapat dipergunakan sebagai alat stimulasi seluruh aspek perkembangan anak yang meliputi aspek moral agama, fisik motorik, kognitif, bahasa, sosial emosional dan seni. Manfaat APE selain untuk membantu pertumbuhan dan perkembangan anak, juga mendorong aktifitas bermain dan membantu menstimulasi kepekaan anak terhadap kondisi lingkungan di sekitarnya. Dalam artikel ini rancang bangun alat permainan edukatif jenis gelinding kelereng untuk pendidikan anak usia dini kelompok usia 4-6 tahun yang sebelumnya dilakukan secara konvensional, dialakukan perbuahan proses rancang bangun menggunakan software CAD dan pencetakan menggunakan 3D printer, proses rancang bangun ini dlakukan agar prosedur rancang bangun menjadi cepat dan bisa dilakukan berulang-ulang.
\end{abstract}

Kata kunci: 3D printer, alat permainan edukatif (APE), software CAD.

\section{PENDAHULUAN}

Pendidikan bagi anak usia dini merupakan proses pendidikan yang sangat fundamental sebagai kerangka dasar pembentukan dan pengembangan dasar-dasar pengetahuan, sikap dan ketrampilan pada anak. Keberhasilan proses pendidikan diusia dini menjadi dasar sangat penting untuk proses pendidikan selanjutnya.

Pembelajaran di lembaga Pendidikan Anak Usia Dini (PAUD) memiliki kekhasan tersendiri sesuai dengan pertumbuhan fisik dan perkembangan psikologi anak. Prinsip dasar pendekatan pembelajaran anak di PAUD meliputi prinsip bermain sambil belajar dan belajar seraya bermain, pembelajaran berorientasi pada kebutuhan anak, pembelajaran berpusat pada anak, pembelajaran menggunakan tematik, pembelajaran pakem, pembelajaran mengembangkan kecakapan hidup, pembelajaran yang didukung oleh lingkungan yang kondusif, pembelajaran yang demokratis dan pembelajaran yang bermakna. Prinsip pembelajaran ini akan mencapai hasil yang maksimal dengan memadukan berbagai metode dan teknik yang memungkinkan semua indera digunakan sesuai karakteristik masingmasing lembaga PAUD (Depdiknas, 2005).

Alat Permainan Edukatif (APE) meerupakan sarana yang dapat dipergunakan sebagai alat permainan yang mengandung makna pendidikan, dan dapat dipergunakan sebagai alat stimulasi seluruh aspek perkembangan anak yang meliputi aspek moral agama, fisik motorik, kognitif, bahasa, sosial emosional dan seni. Manfaat APE selain untuk membantu pertumbuhan dan perkembangan anak, juga mendorong aktifitas bermain dan membantu menstimulasi kepekaan anak terhadap kondisi lingkungan di sekitarnya (Nila, 2014).

\subsection{Pengertian Alat Permainan Edukatif (APE)}

Alat permainan dalam hal ini dapat didefinisikan sebagai semua alat yang digunakan anak untuk memenuhi kebutuhan naluri bermainya. Dalam perkembanganya, didunia pendidikan istilah alat permainan ini dikenal dengan istilah Alat Permainan Edukatif yang disingkat APE.

Alat permainan edukatif adalah alat permainan yang sengaja dirancang secara khusus untuk kepentingan pendidikan (Tedjasaputra, 2001). Alat permainan edukatif adalah alat yang sengaja dirancang secara khusus untuk meningkatkan aspek-aspek perkembangan anak sebagai alat bantu belajar yang didapat mengoptimalkan perkembangan anak, disesuaikan dengna usia dan tingkat perkembanganya (Suryadi, 2007). Direktorat Pendidikan Anak Usia Dini Depdiknas (2003) mendefinisikan alat permainan edukatif sebagai segala sesuatu yang dapat digunakan sebagai sarana atau peralatan untuk bermain yang mengandung nilai edukatif (pendidikan) dan dapat mengembangkan seluruh kemampuan anak. 
Nila Kusumaningtyas dan Yuris Setyoadi, Rancang Bangun Alat Permainan Edukatif Jenis Gelinding Kelereng Untuk Pendidikan Anak Usia Dini Kelompok Usia 4-6 Tahun

\subsection{Software CAD}

Computer Aided Design adalah suatu program komputer untuk menggambar suatu produk atau bagian dari suatu produk. Produk yang ingin digambarkan bisa diwakili oleh garis-garis maupun simbol-simbol yang memiliki makna tertentu. CAD bisa berupa gambar 2 dimensi dan gambar 3 dimensi.

Berawal dari menggantikan fungsi meja gambar kini perangkat lunak CAD telah berevolusi dan terintegrasi dengan perangkat lunak CAE (Computer Aided Engineering) dan Computer Aided Manufacturing (CAM). Integrasi itu dimungkinkan karena perangkat lunak CAD saat ini kebanyakan merupakan aplikasi gambar 3 dimensi atau biasa disebut solid modelling. Solid model memungkinkan kita untuk memvisualisasikan komponen dan rakitan yang kita buat secara realistik. Selain itu model mempunyai properti seperti massa, volume, pusat gravitasi , luas permukaan dll. (www.wikipedia.org).

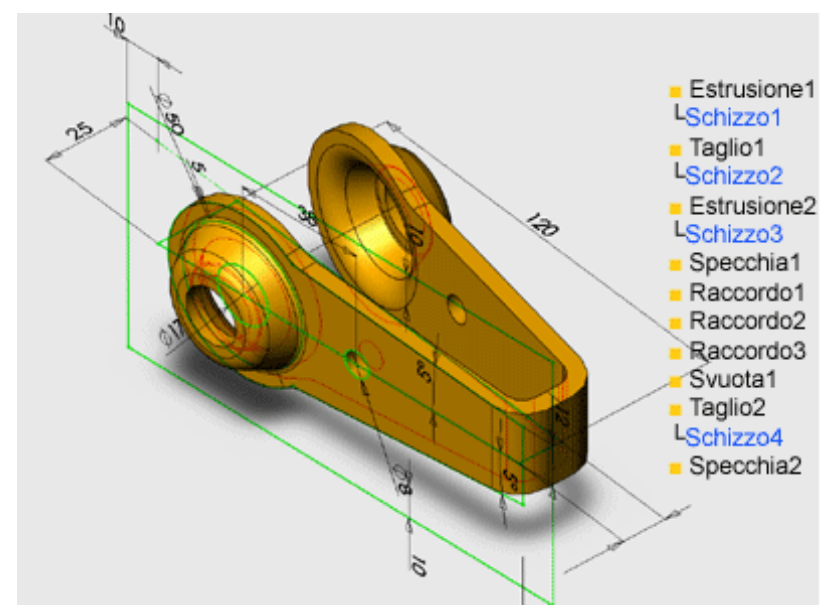

Gambar 1.1 Software CAD (www.wikipedia.org).

\subsection{Pencetakan 3 Dimensi}

Pencetakan 3D (3D Printing) atau manufaktur aditif (aditive manufacturing), adalah proses pembuatan benda padat tiga dimensi dari model digital. Pencetakan 3D ini dibangun dengan proses aditif, di mana lapisan demi lapisan secara berurutan diletakkan dalam bentuk yang berbeda. Pencetakan 3D juga dapat dihasilkan dengan teknik yang berbeda seperti pada teknik mesin tradisional yang umumnya bergantung pada pengurangan bahan (proses subtraktif), misalnya dengan metode pemotongan atau pengeboran. Bahan khas yang digunakan untuk pencetakan 3D (aditive manufacturing) adalah plastik, resin, keramik dan logam.

Pencetakan 3D yang awalnya digunakan terutama produksi prototipe dan model, kemudian untuk produksi produk jadi yang diperlukan dalam jumlah kecil atau bervariasi. Sebagai contoh, pencetakan 3D telah digunakan oleh produsen pesawat Boeing pada bagian laser sintering di jet tempur F-18 Hornet 86.

Ada beberapa keuntungan mendasar yang didapat bila dibandingkan dengan proses manufaktur lainnya dan menyebabkan meningkatnya penggunaan teknologi ini dalam produksi komponen secara massal. Dibandingkan dengan proses injection molding misalnya, pencetakan 3D memiliki keuntungan dalam hal waktu membuat cetakan dan perubahan cetakan yang tidak lagi diperlukan. Dibandingkan dengan semua proses substraktif seperti memotong, membubut, dan pengeboran, cetak 3D memiliki keuntungan dengan tiadanya kerugian material yang terbuang. (www.gudanglinux.com).

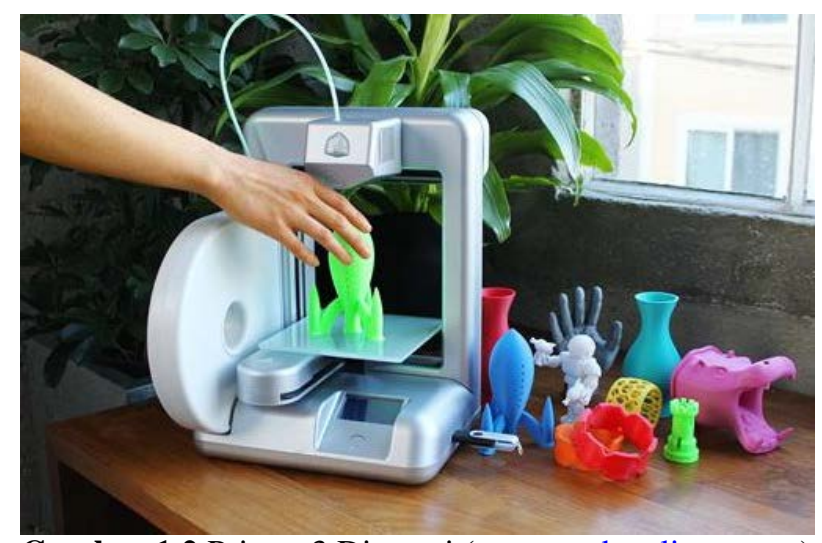

Gambar 1.2 Printer 3 Dimensi (www.gudanglinux.com) 


\section{MATERIAL DAN METODOLOGI}

Desain Alat Peraga Edukatif (APE) yang berkualitas mengandung kompleksitas nilai, keterampilan teknik, muatan filosofi maupun metodologi. Pertimbangan perencanaan desain Alat Peraga Edukatif (APE) meliputi aspek estetika dan fungsional. Desain Alat Peraga Edukatif (APE) edukasi dirancang dengan konsep sesuai dengan tujuan peningkatan produktivitas, kreativitas, estetika, bentuk, dan proporsi. Perancangan desain selalu melewati proses desain untuk menghasilkan kualitas desain yang baik dalam perancangan. (Darmawan Harsokoesoemo. 2004)

\subsection{Proses Desain Alat Permainan Edukatif Jenis Gelinding Kelereng}

Perancangan merupakan serangkaian kegiatan yang berurutan. Kegiatan-kegiatan dalam perancangan dinamakan fase. Setiap fase terdiri dari beberapa kegiatan (disebut langkah-langkah dalam fase). Flowchart Proses Rancang bangun alat permainan edukatif jenis gelinding kelereng untuk pendidikan anak usia 4-6 tahun ditunjukan pada Gambar 2.1 .

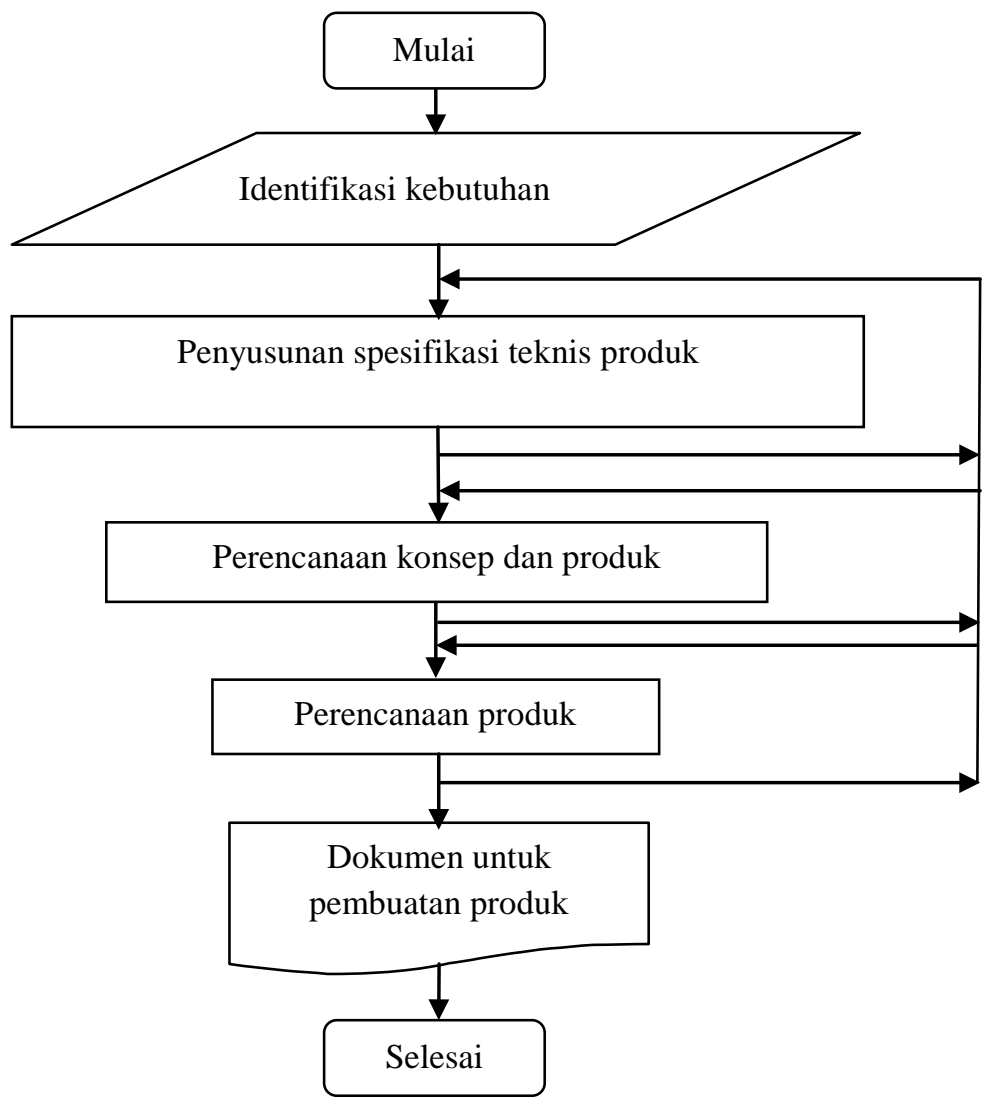

Gambar 2.1 Flowchart Proses Rancang Bangun APE.

Identifikasi kebutuhan dilakukan dengan cara survei ke objek penelitian, yaitu survei ke PAUD Taman Belia dan konsultasi dengan guru PAUD Taman Belia.

Spesifikasi teknis prototipe Alat Peraga Edukatif (APE) antara lain:

- Kinerja

- Dimensi

- Ergonomik

- Harga

- Keamanan (ramah anak)

- Kondisi operasi

Perancangan konsep produk yaitu memilih konsep produk terbaik menjadi produk (yang rencananya akan dibuat) prototipe Alat Peraga Edukatif (APE).

Proses perancangan produk prototipe Alat Peraga Edukatif (APE):

- Pemilihan dari solusi-solusi alternatif

- Penentuan solusi terbaik

- Pembuatan gambar susunan umum

- Penentuan solusi akhir

- Pembuatan gambar susunan dan detail

Dokumen teknis yang dperlukan proses manufaktur produk prototipe Alat Peraga Edukatif (APE): 
Nila Kusumaningtyas dan Yuris Setyoadi, Rancang Bangun Alat Permainan Edukatif Jenis Gelinding Kelereng Untuk Pendidikan Anak Usia Dini Kelompok Usia 4-6 Tahun

- Gambar produk

- Gambar susunan komponen (assembly)

- Gambar detail

- Harga material

Dari beberapa alur proses perancangan didapat bentuk model dan dimensi, data material yang dipakai untuk rancang bangun alat permainan edukatif jenis gelinding kelereng untuk pendidikan anak usia 4-6 tahun ditunjukkan pada Gambar 2.2.

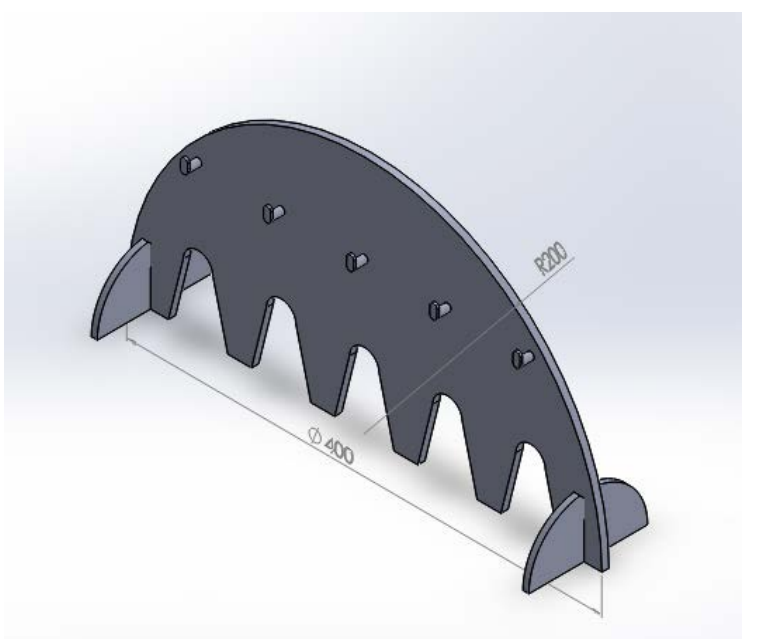

Gambar 2.2. Desain alat permainan edukatif jenis gelinding kelereng.

Detail desain alat permainan edukatif jenis gelinding kelereng dapat dilihat pada Gambar 2.3

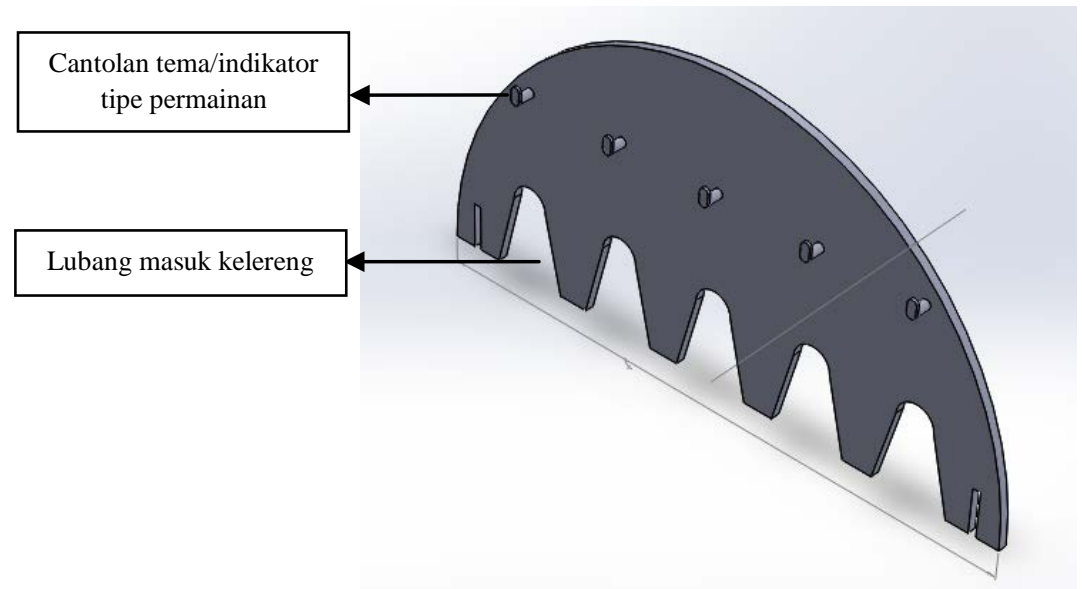

Gambar 2.3 Bodi alat permainan edukatif jenis gelinding kelereng.

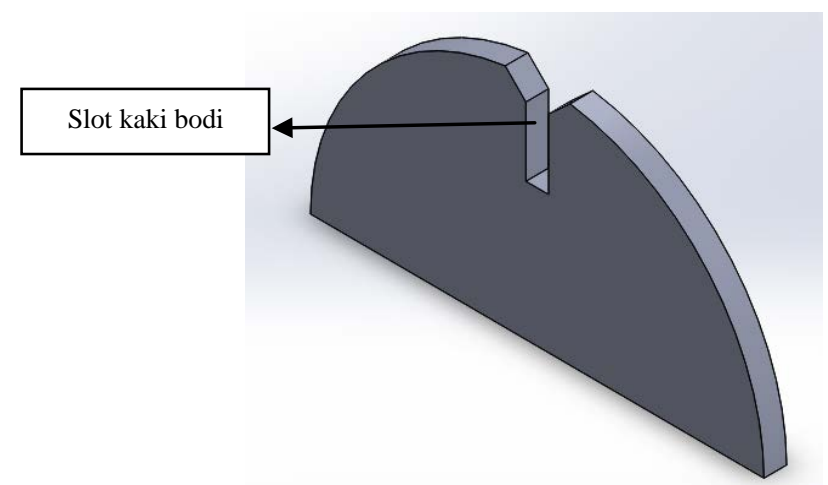

Gambar 2.4 Kaki penyangga alat permainan edukatif jenis gelinding kelereng. 


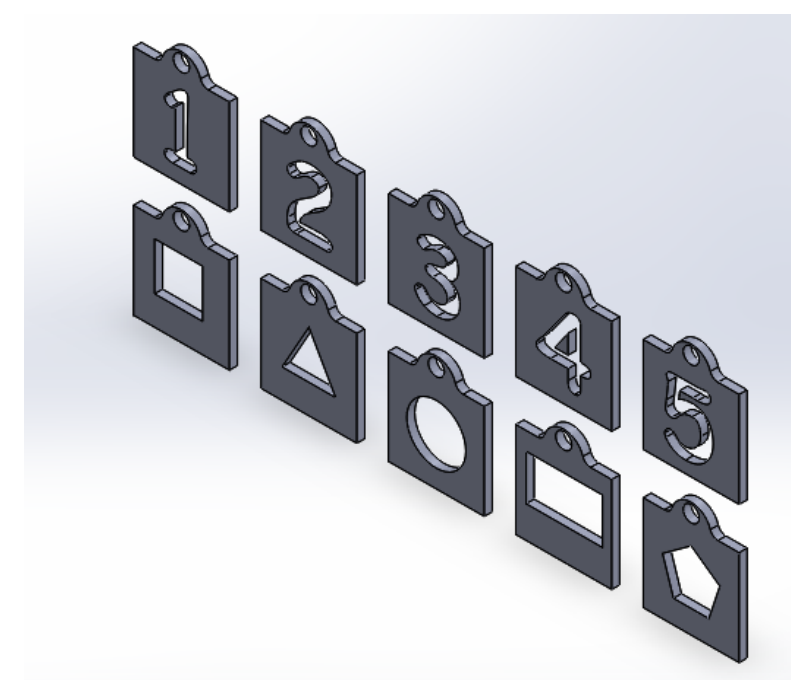

Gambar 2.5 Simbol tema alat permainan edukatif jenis gelinding kelereng.

Desain alat permainan edukatif jenis gelinding kelereng dengan bentuk tersebut mepunyai fungsi sebagai pengembangan nilai moral dan agama, kognitif, bahasa, fisik motorik dan sosial emosional.

\subsection{Proses Manufaktur Proses Alat Permainan Edukatif Jenis Gelinding Kelereng}

Proses manufaktur rancang bangun alat permainan edukatif jenis gelinding kelereng menggunakan 3D Printer yang sebelumnya sudah didesain dengan software CAD, pada proses cetak 3 dimensi dari file CAD dilakukan save as ke dalam bentuk file "stl” bentuk hasil file "stl” ditunjukkan pada Gambar 2.6 dan 2.7.

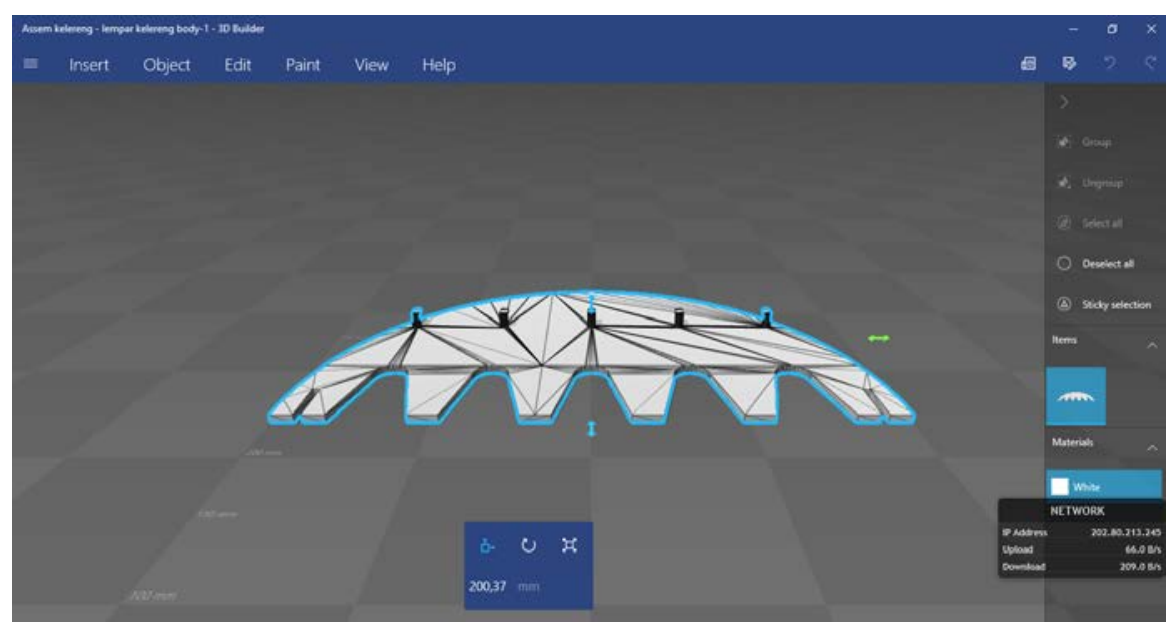

Gambar 2.6 File “stl” bodi gelinding kelereng.

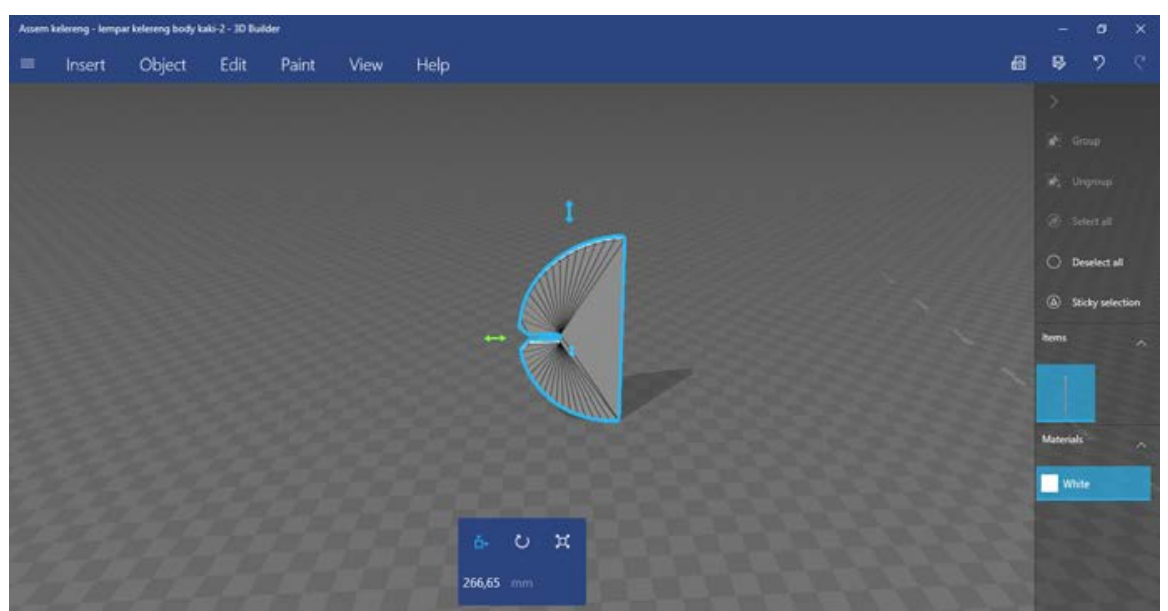

Gambar 2.7 File “stl” kaki penyangga gelinding kelereng. 
Langkah selanjutnya proses pencetakan 3 dimensi menggunakan 3D printer dengan menggunakan material filamen Lay Wood, proses pencatakan 3 dimensi produk dan filamen Lay Wood ditunjukkan pada Gambar 2.8 dan 2.9.

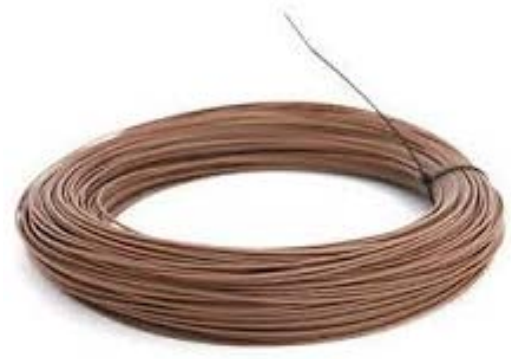

Gambar 2.8 Filamen Lay Wood

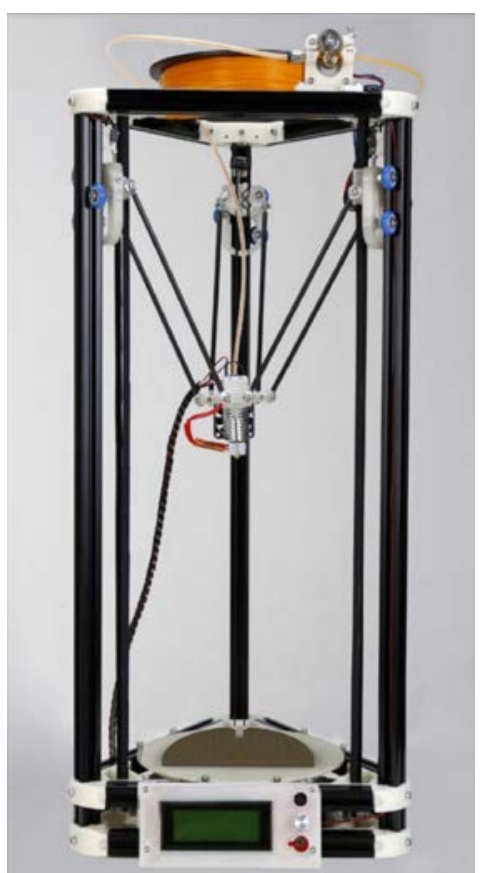

Gambar 2.9 Proses pencatakan 3 dimensi produk

\section{HASIL DAN PEMBAHASAN}

Hasil dari proses manufaktur tiap komponen menggunakan pencetakan 3 dimensi, komponen hasil cetakan 3 dimensi alat permainan edukatif jenis gelinding kelereng yang sudah terakit ditunjukkan pada Gambar 3.1 dan komponen symbol tema alat permainan edukatif jenis gelinding kelereng ditunjukkan pada Gambar 3.2.

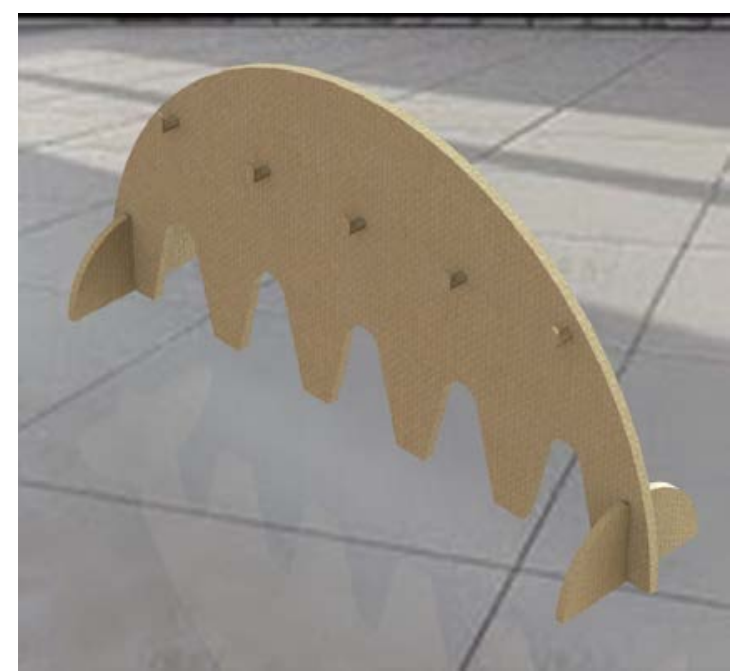

Gambar 3.1 Hasil cetak 3 dimensi alat permainan edukatif jenis gelinding kelereng 


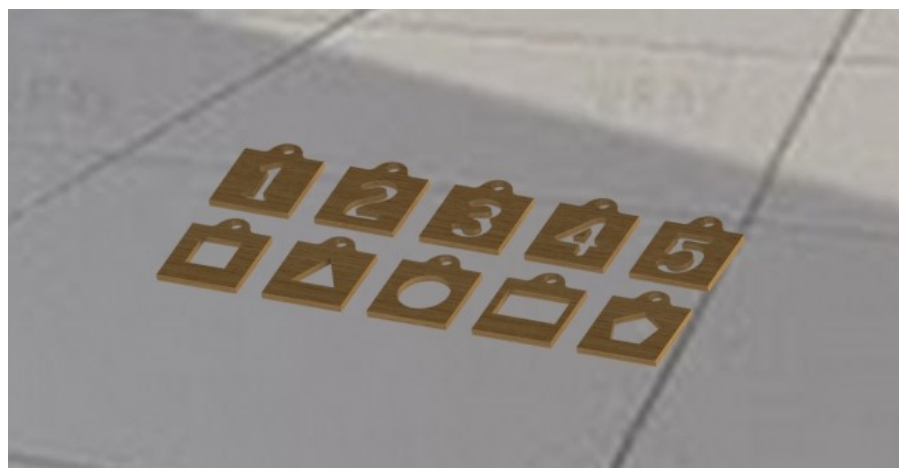

Gambar 3.2 Hasil cetak 3 dimensi Simbol tema alat permainan edukatif jenis gelinding kelereng.

\section{KESIMPULAN}

Rancang bangun dengan menggunakan teknologi saat ini sudah banyak membantu dalam hal membuat produk/komponen tertentu, sehingga desain dan produk jadi dapat terkelola dengan baik, beberapa hal proses rancang bangun alat permainan edukatif jenis gelinding kelereng dapat disimpulkan:

1. Rancang bangun APE/alat peraga edukatif yang sebelumnya dibuat sendiri oleh guru/pendidik pendidikan Anak Usia Dini perlu didampingi pihak orang teknik yang mengerti proses rancang bangun sebuah produk.

2. Desain dan manufaktur perlu peralatan yang cukup mahal untuk membuat suatu produk, sehingga perlu investasi peralatan.

\section{REFERENSI}

[1] Depdiknas. 2005. "Pedoman Pembelajaran Di Taman Kanak-Kanak". Jakarta: Direktorat Pembinaan Taman Kanak-Kanak dan Sekolah Dasar.

[2] Direktorat Pendidikan Anak Usia Dini. 2003. “Alat Permainan Edukatif Untuk Kelompok Bermain”. Jakarta: Depdiknas.

[3] http://gudanglinux.com/glossary/3d-printing/, diakses tanggal 18 November 2016.

[4] https://id.wikipedia.org/wiki/CAD, diakses pada tanggal 18 November 2016.

[5] H. Darmawan Harsokoesoemo. 2004. "Pengantar Perancangan Teknik (Perancangan Produk)". Bandung: ITB.

[6] Nila Kusumaningtyas. 2014. “Alat Permainan Edukatif Untuk Pendidikan Anak Usia Dini”. Karawang: Delacita.

[7] Suryadi. 2007. “Anak Cerdas Dengan Bermain”. Jakarta: Pustaka Media.

[8] Tedjasaputra, Meyke, 2001. “Bermain, Mainan dan Alat Permainan”. Jakarta: Gramedia Widiasarana. 